\title{
nombalina
}

(8)

\section{Amor e morte em Marcial}
Autor(es): $\quad$ Brandão, José Luís Lopes
Publicado por: Humanísticos; Departamento de Estudos Clássicos, Centro de Estudos Clássicos

\author{
URL \\ persistente: \\ URI:http://hdl.handle.net/10316.2/34629 \\ DOI: \\ DOI:http://dx.doi.org/10.14195/978-989-26-0901-0_3
}

Accessed : $\quad$ 26-Apr-2023 12:41:15

A navegação consulta e descarregamento dos títulos inseridos nas Bibliotecas Digitais UC Digitalis, UC Pombalina e UC Impactum, pressupõem a aceitação plena e sem reservas dos Termos e Condições de Uso destas Bibliotecas Digitais, disponíveis em https://digitalis.uc.pt/pt-pt/termos.

Conforme exposto nos referidos Termos e Condições de Uso, o descarregamento de títulos de acesso restrito requer uma licença válida de autorização devendo o utilizador aceder ao(s) documento(s) a partir de um endereço de IP da instituição detentora da supramencionada licença.

Ao utilizador é apenas permitido o descarregamento para uso pessoal, pelo que o emprego do(s) título(s) descarregado(s) para outro fim, designadamente comercial, carece de autorização do respetivo autor ou editor da obra.

Na medida em que todas as obras da UC Digitalis se encontram protegidas pelo Código do Direito de Autor e Direitos Conexos e demais legislação aplicável, toda a cópia, parcial ou total, deste documento, nos casos em que é legalmente admitida, deverá conter ou fazer-se acompanhar por este aviso.

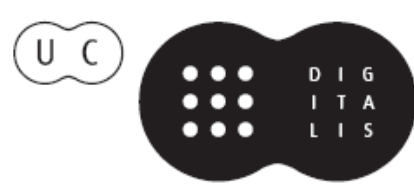




\section{Toto notus in orbe Martialis}

\section{Celebração de Marcial \\ 1900 anos após a sua morte}

Coordenação

Cristina de Sousa Pimentel

Delfim F. Leão

José Luís L. Brandão

Instituto de Estudos Clássicos

Centro de Estudos Clássicos e Humanísticos

UNIVERSIDADE DE COIMBRA
Departamentō de Estudos Clássicos Centro de Estudos Clássicos UNIVERSIDADE DE LISBOA 


\title{
AMOR E MORTE EM MARCIAL
}

\author{
JOSÉ LUÍS LOPES BRANDÃO \\ Universidade de Coimbra
}

Résumé: Dans les épigrammes où l'amour voisine avec la mort, Martial révèle un aspect tout différent de celui qui est le plus connu du public et semble manifester les sentiments les plus sincères. En harmonie avec l'invitation au carpe diem - la jouissance de chaque moment de la vie tout en cultivant l'amitié - le poète se sent navré face au trépas inattendu et prématuré de ses amis dans des épigrammes qui ressemblent à une oblation à la mort, surtout lorsque la distance l'empêche de leur rendre les honneurs funèbres, et qui servent en quelque sorte à les rendre éternels. Il se sent révolté avec le malheur des pauvres et des sans défense, esclaves ou enfants, victimes de $\mathrm{l}^{\prime}$ arbitraire des hommes ou des dieux, et il pleure la mort de ses propres serfs dans de belles épitaphes, comme celle de Demetrius, son esclave copiste, à qui il a accordé, in extremis la liberté, et tout particulièrement la petite esclave Erotion, don't il se souvient au moment du retour à Bilbilis. Sa façon de condamner, par principe, le suicide stoique, met en évidence le prix qu'il accorde à la vie, sans pour autant laisser de louer les gestes héroiques de Festus, de Porcia, d' Arria et $\mathrm{d}^{\prime}$ Othon. Mais, à la fin de sa vie, Martial laisse apercevoir son désenchantement lorsqu' il constate que le retour tant désiré à la terre natale, Bilbilis, ne correspond plus à ce don't il rêvait: il mourra dans un monde qui n'est plus le sien, loin de l'Urbs, qui trente quatre ans durant l'avait inspiré, loin aussi du commerce de ses amis. Tout en conseillant l'éloignement qui permet d'eviter la souffrance au moment des grandes pertes, le poète ne réussit pourtant pas à échapper aux "morsures de l'âme".

Quidquid ames, cupias non placuisse nimis. Marcial, 6.29 .8

Falar de amor e morte pode parecer, à primeira vista, descabido, a propósito de um poeta que canta sobretudo as alegrias da vida, que 
busca argumentos vivos de Roma, ${ }^{1}$ que cultiva um género considerado leve e propenso a desencadear o riso, e de quem, ao contrário de Catulo, se tornaram mais conhecidos os epigramas que foram apartados das edições ad usum Delphini do que os que falam de amor verdadeiro.

No meio de epigramas jocosos, é com cepticismo que olhamos os vagos sinais de amor dirigidos para algumas mulheres ou efebos: sabem a mero artifício poético. Podemos duvidar até de certas manifestações de amizade: acaso ditadas pela circunstância ou pela adulação. Mas dificilmente duvidamos da sinceridade das expressões de afecto para com amigos mortos ante diem. E mais convincente se torna o lamento, se os pranteados não passam de simples escravos, para mais, crianças. É a morte que arranca à pena do poeta a mais pura e sentida expressão do amor. Os epigramas em que o amor, nas suas várias dimensões, se manifesta ligado à morte - e são em número considerável - apresentam-nos um poeta muito diferente da faceta mais conhecida do público: a do Marcial chocarreiro, irónico, mordaz e, por vezes, até cruel, que elege Talia como a sua musa inspiradora.

Convém, apesar de tudo, distinguir entre sentimentos expressos na letra dos epigramas e sentimentos reais de Marcial, dificilmente atingíveis. Epitáfios, epicédios ou outras composições do género, como as que se seguem, não serão as mais adequadas para buscar sentimentos pessoais: de mortuis nihil, nisi bonum. De qualquer modo, em certos casos, será significativo o facto de Marcial elaborar desinteressadamente um epigrama sepulcral.

Uma das virtudes mais creditadas a Marcial é o afecto que dedica aos amigos. Mas existe na sua poesia uma tensão entre a amizade e os agentes perturbadores do bom relacionamento. Um é a falta de disponibilidade, patente na dor das palavras dirigidas a Deciano, o amigo e patrono estóico, que, devido aos seus variados afazeres, se furta às visitas do poeta: «Para te ver, andar dois mil passos, não me pesa; / para te não

'Cf. 10.4.8-10: hoc lege, quod possit dicere uita 'meum est'. I Non hic Centauros, non Gorgonas Harpyasque / inuenies: hominem pagina nostra sapit. Usamos o texto fixado por ShackLeton Bailey (Estugarda, Teubner, 1990). Ao Prof. Walter de Medeiros agradecemos os conselhos e sugestões que nos deu para o aperfeiçoamento deste estudo. 
ver, andar quatro mil, isso já me pesa!». ${ }^{2}$ No entanto, o mais definitivo dos agentes perturbadores da amizade é a morte, a grande ameaça que paira, pronta a arrebatar ao convívio os amigos. Por isso, o poeta rejubila com a recuperação de Gaio Júlio Próculo, o amigo e protector ${ }^{3}$ que julgava já perdido. Celebra a convalescença com uma alegria tanto maior quanto fora o desespero da cura. E nada melhor, para festejar a vitória sobre a morte, do que verter o falerno imortal (11.36).

Mas as fragilidades humanas lembram-nos continuamente de que somos mortais. A experiência da doença aviva a saudade dos amigos ausentes que podemos não voltar a ver. Enquanto Aulo Pudente, um amigo dos verdadeiros ${ }^{4}$ andava em campanha militar junto ao Danúbio, o poeta adoeceu gravemente: «oh, quase arrebatado a ti para as águas estígias, / como eu vi as nuvens torvas das praias elísias! / A luz de meus olhos buscava, cansada embora, o teu rosto, / e a minha língua gelada repetia sem cessar 'Pudente'!». ${ }^{5}$

A percepção da ameaça da morte parece gerar no poeta uma ânsia de fruir ao máximo cada momento na companhia dos amigos. O convite ao

2 2.5.7-8: Te tamen ut uideam, duo milia non piget ire; / ut te non uideam, quattuor ire piget.

${ }^{3}$ Marcial mostra alguma familiaridade com este patrono, ao ponto de se escusar do incumprimento dos deveres de cliente com a desculpa espirituosa de que enviava o livro em seu lugar, pois a vida de cliente lhe roubava o tempo para a produção literária (1.70). Também a Licínio Sura, hispânico ilustre, mencionado em 1.49.40, dedica Marcial um soterion que termina com uma exortação à vida: uiue uelut rapto fugitiuaque gaudia carpe: / perdiderit nullum uita reuersa diem (7.47.11-12). Sullivan, J. P., Martial: the unexpected classic. A literary and historical study (Cambridge, University Press, 1991) 19, estranha o facto de tão brilhante filho da Hispânia (Sura foi favorecido por Trajano) não voltar a ser referido, mas nota que nem sempre foi bem sucedida a abordagem do poeta a certos patronos.

4 Parece ter havido grande intimidade entre Marcial e este centurião primipilo (promoção que o poeta festejava em 1.31), que mais tarde terá ascendido à ordem equestre (como Marcial augurava em 6.58.10). Aulo Pudente teria grande estima por Marcial e pela sua obra, como se lê em 7.11.3-4: O quam me nimium probas amasque / qui uis archetypas habere nugas. SULLIVAN, J. P. (1991) 18.

${ }^{5}$ 6.58.3-6: O quam paene tibi Stygias ego raptus ad undas / Elysiae uidi nubila fusca plagae! / Quamuis lassa tuos quaerebant lumina uultus / atque erat in gelido plurimus ore Pudens. 
carpe diem horaciano é dirigido repetidamente ao grande amigo Júlio Marcial. Logo no epigrama 15 do livro I o adverte: "Olha que não fazes bem em adiar o que pode ser negado / e considera teu somente o que passou...», ${ }^{6}$ para terminar com a máxima: "Acredita em mim; não é próprio do sábio afirmar 'hei-de viver': / demasiado tardia é a vida de amanhã. Vive hoje!».7 Em outro epigrama (5.20), para o mesmo destinatário, verificamos que, segundo Marcial, fruir os dias equivaleria a passar o tempo livre, se dele pudesse dispor, no convívio do amigo: deixariam de lado as fastidiosas obrigações que lhes impunha a vida de cliente, para se dedicarem aos passeios de conversa literária pelos espaços de lazer do Campo de Marte. Mas o fecho é uma constatação amarga: "Agora nenhum dos dois vive para si mesmo, / cada qual sente fugir e desvanecer-se os dias felizes / que para nós morrem e são contados. / Quem é que, sabendo viver, anda a perder o tempo?».8 É, pois, na companhia de Júlio Marcial que o poeta diz, mais tarde (11.80), preferir gozar as delícias de Baias. É ainda a este confidente que Marcial dedica o célebre epigrama sobre a uita beatior (10.47), com exemplos de simplicidade de vida, tranquilidade e moderação, que levam a não temer nem desejar o último dia. ${ }^{9} \mathrm{E}$ já na quietude de Bílbilis o poeta há-de celebrar os trinta e quatro anos de convívio (12.34), com um misto de saudade e pessimismo que parece adivinhar a proximidade da morte.

Exortação semelhante é feita a Quinto Ovídio, vizinho do poeta em Nomento, que, apesar de já não ser jovem, se prepara para nova viagem: «As alegrias, tu adia-las, mas os fios da vida não adia / Átropo, e cada hora fica para ti gravada.».10 Devido à constante ameaça da morte, o que dá o valor à vida são os verdadeiros sentimentos. Por isso, o poeta diz prezar mais o aniversário do nascimento do amigo que o próprio: se as

${ }^{6}$ 1.15.5-6: Non bene distuleris uideas quae posse negari, I et solum hoc ducas, quod fuit, esse tuum.

7 1.15.11-12: Non est, crede, mihi, sapientis dicere 'uiuam': / sera nimis uita est crastina: uiue hodie.

8 5.20.11-14: Nunc uiuit necuter sibi, bonosque / soles effugere atque abire sentit, / qui nobis pereunt et imputantur. / Quisquam uiuere cum sciat, moratur?

${ }^{9} \mathrm{E}$, ao fazer o elogio da vida calma que leva em Bílbilis, Marcial confessará a outro amigo, Juvenal: Sic me uiuere, sic iuuat perire (12.18.26).

10 10.44.5-6: Gaudia tu differs, at non et stamina differt / Atropos atque omnis scribitur hora tibi. 
calendas de Março lhe deram a vida, as de Abril, em que Ovídio nasceu, lhe deram um amigo (9.53). De resto, Quinto Ovídio é exemplo para o poeta, pois considera a fides da amizade mais valiosa que a vida (10.44), convicção que o destinatário deste epigrama demonstrou ao acompanhar na desgraça Cesónio Máximo, condenado ao exílio por Nero (7.44; 7.45). Ao consolar Quinto Ovídio pela recente morte de Cesónio, Marcial louva-o pelo laço que os uniu: uma amizade que considera digna de se tornar imortal nos epigramas, ${ }^{11}$ como imortal se tornara o exemplo de Pílades e Orestes (7.45).

Desta visão da amizade e da vida resulta uma profunda tristeza pela perda dos que estão próximos. Um dos motivos reiterados por Marcial centra-se na morte longe do amor da família e dos amigos, como é o caso de Camónio Rufo, natural de Bonónia, 12 morto na Capadócia, quando contava apenas vinte anos (6.85). O poeta coloca em relevo a jovem idade do defunto e lamenta que o amigo já não veja a edição do livro VI dos Epigramas ${ }^{13}$ Marcial, que amiúde se mostra reconhecido para com aqueles que apreciam a sua poesia, lembra que o amigo costumava recitar de cor os seus versos. A sublinhar a tristeza da morte ocorrida em terra longínqua, o poeta faz saber que esta breve composição representa a homenagem que a distância impede de tributar a quem partiu: "Aceita com triste pranto o breve canto de um amigo / e toma-o qual incenso deste que está ausente.».14

Como se trata de pessoas poderosas, não evitamos pensar que, a despeito da amizade, o objectivo seja agradar ao pai do morto. De qualquer modo, alguns anos depois, em 95, Marcial ainda recorda o amigo. Imortaliza em dois epigramas (9.74 e 9.76) um retrato de Camónio Rufo,

11 7.44.7-8: Si uictura meis mandantur nomina chartis / et fas est cineri me superesse meo: / audiet hoc praesens uenturaque turba fuisse / illi te, Senecae quod fuit ille suo.

12 Sullivan, J. P. (1991) 30-31, põe a hipótese de se tratar do mesmo Rufo a quem o poeta apresenta o livro III (3.97) e endereça amigavelmente alguns epigramas deste livro $(3.82 ; 3.94)$. Abona a favor desta identificação o facto de o livro III ter sido publicado, em 87, a partir do Forum Cornelii (a actual Ímola), situado a $33 \mathrm{~km}$ de Bonónia, também referida neste livro (3.59.1). Vide ID. 157.

13 Publicado em 91. Vide Sullivan, J. P. (1991) 37.

${ }^{14}$ 6.85.11-12: accipe cum fletu maesti breue carmen amici / atque haec absentis tura fuisse puta. 
ainda criança, que o pai deste mandou fazer. E deixa-se tocar pela imagem infantil daquele que virá a perecer na flor da idade (9.74). De novo se realça o carácter prematuro da morte, atribuída à inveja das Parcas. E, mais uma vez, o poeta regista o acréscimo de dor, que uma morte peregrina veio trazer, com a expressão «A urna restitui ao pai as cinzas de uma pira ausente.». ${ }^{15}$

A maior dádiva com que se pode presentear um amigo é conceder-lhe a imortalidade, como testemunhará mais tarde Plínio, a propósito de um epigrama que acerca dele compôs o poeta de Bílbilis. ${ }^{16}$ Uma pintura, como a de Camónio Rufo, pode corromper-se; mas os versos, se têm algo de génio, não morrerão - diz Marcial em outro passo. ${ }^{17} \mathrm{O}$ poeta, que pugna, em vários epigramas, pelo reconhecimento da sua poesia, que demonstra repetidamente ter consciência do próprio valor, ${ }^{18}$ que se recusa a incluir certos nomes nos seus escritos ${ }^{19}$ e mostra prazer em honrar quem o mereceu (5.15), encarece assim a dedicação ao amigo: «Mas, para que não só a pintura nos fale do rapaz, / esta imagem maior ficará nos meus escritos.».20

O tema da morte longe da pátria e da concessão da imortalidade através da poesia é retomado a propósito do centurião Varo, falecido no Egipto: «Repousas, sombra estrangeira da praia dos Lágidas. / Aspergir

15 9.76.8: absentemque patri rettulit urna rogum.

16 Embora este autor manifeste cepticismo em relação à imortalidade dos epigramas. Plínio, Ep. 3.21: (...) Dedit enim mihi quantum maximum potuit, daturus amplius si potuisset. Tametsi quid homini potest dari maius, quam gloria et laus et aeternitas? Aeterna, quae scripsit, non erunt fortasse: ille tamen scripsit tamquam futura.

${ }^{17}$ Cf. 661.9-10: Nesquiquid plus est, quod donat saecula chartis: / uicturus genium debet habere liber.

${ }^{18}$ Cf., entre outros, $1.1 ; 2.8 ; 3.1 ; 4.49 ; 5.13 ; 5.95 .5-11 ; 7.84 .5-8 ; 8.3 ; 9$. pref.; 10.4 ; $10.100 ; 11.42$.

19 Marcial, consciente da honra que é para alguém ter o nome nos seus epigramas (cf. 5.15), recusa-a a quem não a merece, como o maldizente a quem condena a morrer desconhecido (5.60) ou o fulano cuja identidade esconde sob o falso nome de Ligurra (12.61), possivelmente um nome falante, ligado ao sentido obsceno de ligurrio, como sugere PAVANELLO, Renata, "Nomi di persona allusivi in Marziale": Paideia 49 (1994) 166-167.

20 9.76.9-10: Sed ne sola tamen puerum pictura loquatur, / haec erit in chartis maior imago meis. 
com lágrimas o teu rosto frio não me foi permitido, / nem juntar à pira triste incenso em abundância, / mas é concedido ao teu nome viver neste eterno canto: / e esta honra, pérfido Nilo, podes também negá-la?». ${ }^{21}$ Se a morte arrebata os amigos, a amizade deixa marcas de imortalidade na vida que se apresenta breve e ameaçada pelo arbítrio das Parcas.

Outra característica muito encarecida em Marcial diz respeito ao afecto pelas crianças e pelos escravos. ${ }^{22}$ Revelam a humanidade do poeta os epigramas sobre a morte dos humildes e indefesos, vítimas da violência dos homens ou dos deuses. É brutal a denúncia da crueldade de um senhor: «Porque crucificas um escravo, Pôntico, com a língua cortada? / Não sabes tu que o que ele cala, o conta o povo?».23 É com palavras de revolta que o poeta reage à morte nefasta de duas crianças, dilaceradas, quando limpavam a arena, por um leão amestrado, que suportava o chicote do domador e até deixava que lhe introduzissem a mão na boca: «Apetece gritar: 'Cruel, pérfido, predador, / aprende da nossa loba a poupar as crianças!'. ${ }^{24}$

Também os golpes do destino se tornam verdadeiros crimes para o poeta, quando as vítimas não passam de crianças inocentes. A descrição destas fatalidades desemboca, no final, em brados de indignação. ${ }^{25}$

21 10.26.4-8: hospita Lagei litoris umbra iaces. I Spargere non licuit frigentia fletibus ora / pinguia nec maestis addere tura rogis. / Sed datur aeterno uicturum carmine nomen: / numquid et hoc, fallax Nile, negare potes? SULLIVAN, J. P. (1991) 48, sugere que este epitáfio possa ter sido encomendado.

22 Vide MEdeiros, W. de, "O poeta que buscava um amor": Biblos 64 (1988) 13-15; BRANDÃo, J. L., Da quod amem. Amor e amargor na poesia de Marcial (Coimbra, Colibri / Faculdade de Letras, 1998) 119-130.

23 2.82: Abscissa seruom quid figis, Pontice, lingua? / Nescis tu populum, quod tacet ille, loqui?

24 2.75.9-10: Exclamare libet: 'Crudelis, perfide, praedo, I a nostra pueris parcere disce lupa!'

${ }^{25}$ Certos acontecimentos imprevisíveis, que começam por ser apresentados objectivamente, para o que contribuem claras notações espaciais, motivam, no final, um aproveitamento subjectivo, revelador, ao mesmo tempo, da argúcia e da sensibilidade do poeta: $3.19 ; 4.18 ; 11.82$. No mesmo rol se inclui a morte de insignificantes insectos, uma abelha e uma formiga, que se tornam preciosos depois de aprisionados por uma gota de âmbar (respectivamente 4.32 e 6.15). Vide. Sullivan, J. P. (1991) 226-227. A estes exemplos podemos acrescentar o 
O carácter traiçoeiro da morte está patente no destino de Hilas, que, ao brincar junto a uma inofensiva ursa de bronze, lhe meteu a tenra mão na boca, sem saber que aí se escondia uma víbora: «o menino não se apercebeu do dolo senão depois da picada, / já moribundo. Que crime atroz, ser esta ursa traiçoeira!». ${ }^{26}$ Mas a quem referir as culpas? A tradição poética manda que sejam atribuídas à Fortuna, às Parcas, à inveja dos deuses. Dos inesperados golpes da Fortuna saeua é exemplo a lâmina de gelo que, desprendida de uns arcos do aqueduto, junto ao pórtico de Agripa, corta a garganta de um menino e, paradoxalmente, acaba por derreter com o calor da ferida mortal. O comentário pessimista patenteia o motivo trágico decorrente da fragilidade do homem e da sua incapacidade para prevenir tais insídias: "Que caprichos não quis permitir-se a Fortuna cruel? / Ou onde não pára a morte, se até vós, ó águas, sois degoladoras?». ${ }^{27}$

Scelus, facinus - assim é designada a morte de Cánace, não tanto pela brevidade da vida, mas pela forma como adveio o fim: uma chaga horrenda devorou-lhe parte do rosto. No fecho do epitáfio ecoa a expressão quase ímpia da revolta: «Se haviam de chegar com tão precipitado voo / deviam os fados chegar por outra via. / Mas apressou-se a morte a atalhar o caminho à meiga voz, / não fosse ela vergar com a língua as deusas inflexíveis.». ${ }^{28}$

Influenciado ou não pelas ideias de Séneca, Marcial considera um escravo como um homem (10.31.5-6). Se censura a prepotência, mostra-se, por outro lado, sensível ao sofrimento de alguns senhores, perante a

epigrama sobre a erupção do Vesúvio (4.44): à descrição das riquezas vinícolas da encosta do vulcão e do favor dos deuses que tutelavam as cidades de Herculano e Pompeios, segue-se o comentário de que uma tal calamidade nem os deuses desejariam que lhes fosse permitida.

26 3.19.7-8: Non sensit puer esse dolos, nisi dente recepto / dum perit. O facinus, falsa quod ursa fuit!

${ }^{27}$ 4.18.7-8: Quid non saeua sibi uoluit Fortuna licere? / Aut ubi non mors est, si iugulatis, aquae?

${ }^{28}$ 11.91.9-12: Si tam praecipiti fuerant uentura uolatu, / debuerant alia fata uenire uia. I Sed mors uocis iter properauit cludere blandae, I ne posset duras flectere lingua deas. A injustiça das Parcas está também expressa no epitáfio do menino Úrbico, filho de Basso, que morreu aos dois anos e meio (7.96): ruperunt tetricae cum male pensa deae. 
perda de um servo dedicado, ao mesmo tempo que se solidariza com o luto dos amigos. Nestes epigramas, a despeito de alguns poderem ser escritos de encomenda, surge repetidamente o tema do amor do patrão e consequente dor da perda. Assim contece com o escravo do poeta Cástrico, Êutico, morto nas águas de Baias, a quem Marcial dedica um epicédio cheio de referências mitológicas (6.68). Também para Gláucias, escravo de Mélior, protector do poeta, compõe um epigrama em forma de epitáfio (6.28), seguido de um lamento pela morte precoce do jovem, quando contava apenas doze anos (6.29). Celebra, repetidamente, a grande afeição do senhor ao escravo ${ }^{29}$ e a generosidade da manumissão, in extremis, parece - dádiva engrandecida pelo facto de Gláucias ser ainda incapaz de compreender as suas implicações. ${ }^{30} \mathrm{E}$ a conclusão pessimista do epigrama deixa implícito o topos da inveja dos deuses: «Breve é o tempo das grandes almas e rara a velhice: / a tudo o que amares, não desejes que te encante em demasia.» ${ }^{31}$ - uma receita racional para prevenir futuros sofrimentos, mas difícil de pôr em prática.

O apego de Marcial aos seus próprios escravos torna-se patente na forma como lamenta a morte deles. Serve-se dos mesmos topoi, dando-lhes naturalmente o desenvolvimento adequado à situação pessoal. Não é fácil enumerar com segurança todos os possíveis escravos de Marcial referidos nos epigramas, ${ }^{32}$ mas alguns ficaram imortalizados de modo especial porque o poeta se sentiu tocado com a sua morte precoce. No epitáfio de Pantágato, que poderá ter sido escravo do poeta, juntamente com o motivo do afecto e da saudade do patrão (domini cura dolorque sui) fica imortalizada a arte humilde de barbeiro, na qual o jovem era exímio: a leveza da terra, da fórmula sepulcral, é usada para exaltar a leveza da mão do artista (6.52). A Álcimo ${ }^{33}$ o poeta oferece um monumento, ornado, não com o mármore de Paros, mas de singelas verduras, regadas

29 6.28.3: cari deliciae breues patroni; 6.29.2: sed domini sancto dignus amore puer.

30 6.29.3-4: munera cum posset nondum sentire patroni, / Glaucia libertus iam Melioris erat.

31 6.29.7-8: Immodicis breuis est aetas et rara senectus. I Quidquid ames, cupias non placuisse nimis.

32 Uma lista provável dos escravos de Marcial, elaborada a partir dos epigramas, pode ler-se em SulLIVAN, J. P. (1991) 164 n.59; vide também 27.

33 Poderá tratar-se do minister a quem o poeta se dirige em 5.64.2. 
com as suas próprias lágrimas. O trabalho do mármore é vão, está condenado a ruir, ${ }^{34}$ enquanto os monimenta doloris do poeta, expressos nas palavras deste epigrama, são homenagem que viverá pelos tempos fora. ${ }^{35}$ $\mathrm{O}$ autor termina com o desejo de que assim possam repousar as suas futuras cinzas, sem deixar claro se está a pensar na simplicidade do túmulo ou na perenidade do lamento.

Para com o escravo amanuense, Demétrio, ${ }^{36}$ Marcial toma a atitude que louvara a Mélior, mas desta vez o rapaz, que tinha dezanove anos, compreende o significado da manumissão. Este prémio derradeiro demonstra o afecto do senhor e é uma forma de reconhecer o mérito do moribundo, que, na vida como na morte, merecera tornar-se livre: «Para que não descesse escravo às estígias sombras, / pois que o queimava, entranhada, uma doença horrível, / providenciei, e a todo o direito de posse sobre o doente renunciei: / era justo que recuperasse a saúde com a minha dádiva. / Ele entendeu, ao morrer, a sua recompensa e 'patrono' / me chamou, enquanto se dirigia, livre, às águas infernais.». ${ }^{37}$

Mas o enlevo do poeta era Erócion, que não chegou a completar os seis anos $\left(5.34 ; 5.37\right.$; 10.61). ${ }^{38}$ Frontão e Flacila - talvez os falecidos pais de Marcial -, ficam encarregados de velar pela menina: não vá ela assustar-se com as sombras infernais ou com a bocarra do cão do Tártaro. É comovente o desejo do poeta de que ela não esqueça o nome do seu amo e o continue a papaguear na sua língua de trapos (5.34) - anseio,

${ }^{34}$ 1.88.3-4: accipe non Pario nutantia pondera saxo, / quae cineri uanus dat ruitura labor.

35 1.88.7-8: accipe, care puer, nostri monimenta doloris: / hic tibi perpetuo tempore uiuet honor.

36 Teria a função de transcrever pequenas colecções de epigramas apropriados para enviar aos patronos de Marcial; vide Sullivan, J. P. (1991) 5 e 123.

37 1.101.5-10: Ne tamen ad Stygias famulus descenderet umbras, / ureret implicitum cum scelerata lues. / cauimus et domini ius omne remisimus aegro: / munere dignus erat conualuisse meo. / Sensit deficiens sua praemia meque patronum / dixit ad infernas liber iturus aquas.

38 Colton, R. E., "Children in Juvenal and Martial": CB 56 (1979) 1-3, deixa-se fascinar com o facto de poetas por vezes tão azedos e desiludidos, como Juvenal e Marcial, demonstrarem tal ternura pelas crianças e regista os epigramas sobre Erócion entre os mais memoráveis. 
senão de um pai verdadeiro, como há quem sugira, ${ }^{39}$ pelo menos de alguém que a recorda com ternura e saudade. ${ }^{40}$ Apesar da influência da tradição do epigrama sepulcral, pode adivinhar-se o sentimento: a própria fórmula do último dístico liga a suavidade da terra à delicadeza da menina: «Um torrão não rijo cubra os seus ossos macios, e para ela, / terra, não sejas pesada: ela não o foi para ti.».

O afecto por Erócion aparece encarecido noutro epigrama (5.37), embora a estrutura desta composição tenha causado perplexidade e divergência de interpretação entre os estudiosos. ${ }^{41}$ Depois de descrever longamente, através de expressivas comparações e metáforas, a beleza, a

${ }^{39}$ Impressionado com a profundidade dos sentimentos demonstrados, BELL, A. A. Jr., "Martial's daughter?": CW 78 (1984) 21-24, põe a hipótese de Erócion ser filha de Marcial e de uma das suas escravas.

40 Dir-se-ia que o poeta mantém viva a esperança de se voltar a encontrar com Erócion numa outra vida, como sugere DolÇ, M., M. Valerio Marcial. Epigramas selectos. intr., selecc., notas y voc. por -, (Barcelona, Bosch, 1981) 126.

${ }^{41}$ Com efeito, há quem duvide da seriedade destes epigramas e proponha a leitura conjunta dos dois epigramas, em que o segundo (5.37) seria uma subtil palinódia com fins humorísticos. LloyD, L. J. "Erotion: a note on Martial": $G$ ER 22 (1953) 39-41, questiona a sinceridade dos sentimentos expressos nos versos 1 a 17 do epigrama 5.47. Já KENNEY, E. J., "Erotion again": GER 11 (1964) 77-81, embora defenda a leitura autónoma dos dois epigramas (5.34 e 5.37), com o argumento de que o leitor contemporâneo de Marcial esperaria, de acordo com os princípios da variação, um tratamento diferente no segundo epigrama, e não questione a sinceridade dos sentimentos do poeta expressos em 5.47, nota, contudo, que as metáforas usadas nos versos 1-13, não devem ser tomadas seriamente, por se tratar de expressões da linguagem infantil (baby-talk), que Marcial usaria com a criança quando esta era viva. WATSON, P. "Erotion: puella delicata? ": CQ 42 (1992) 253-268, acha que os primeiros 17 versos do epigrama não devem ser tomados seriamente, mas por outra razão: a série de comparações é característica de situações eróticas, pelo que Erócion, a despeito da sua tenra idade, seria uma puella delicata que o poeta recordava com afeição. Mas tal interpretação parece abusiva em relação a um poeta que condena várias vezes a exploração sexual de crianças escravas por parte dos senhores ou senhoras (por ex., 11.70; 12.16; 12.33; 12.86; 12.97; 7.14; ). Permanece, no entanto, o problema da maior ou menor seriedade do epigrama, num poeta que elege como recursos principais a ironia e o humor, como cautamente observa SullivAN, J. P. (1991) 212-215. 
candura e a fragilidade da criança, o poeta ironiza com o seu amigo Peto, que lhe censura as manifestações de luto por uma simples escrava nascida em casa. É que Peto perdera uma esposa ilustre e rica e não se deixou vencer pelo desânimo. "Quem pode ter um coração mais forte que o meu Peto? / Herdou vinte milhões e, no entanto, continua a viver.». ${ }^{42} \mathrm{O}$ tom jocoso, que se insere abruptamente no final do epigrama e lhe confere um objectivo inesperado, não vem, no entanto, apoucar a qualidade do afecto do poeta por Erócion, mas apenas do de Peto pela esposa. As palavras hiperbólicas dos primeiros dezassete versos, que constituem uma espécie de elogio fúnebre, contrastam com o conteúdo sarcástico da parte final; e pode causar estranheza que o poeta tenha usado a morte da escravinha como tema de uma composição espirituosa ${ }^{43}$ Mas, se tivermos em conta a organização dramática do epigrama, o elogio, acaso exagerado, torna-se a exemplificação do comportamento que é objecto de censura, na medida em que constitui a primeira "fala" do poeta: a que motiva o reparo de Peto. A expressão com que Marcial resume o significado que para si tinha Erócion, «meu amor e minha alegria e minha distracção» (v.17: nostros amores gaudiumque lususque), opõe-se à fórmula com que o interlocutor se refere à esposa «ilustre, magnífica, nobre, rica» (v.22: notam, superbam, nobilem, locupletem), mas onde, como nota Kenney, ${ }^{44}$ falta a qualidade de amatam. Se é lícito desconfiarmos que "por trás do sal há al", da frechada última só se poderá deduzir que, acima das convenções sociais, eştá a natureza do amor: o lamento da morte de Erócion nada tem de socialmente censurável, porque desinteressado e sentido: através do confronto irónico de sentimentos, Marcial justifica a subversão social que representa o luto por uma simples uernula. Independentemente da abordagem que se faça do epigrama, a sua interpretação não pode ser separada da gratuidade da ternura do poeta pelas crianças e pelos escravos pequenos.

42 5.37.23-24: Quid esse nostro fortius potest Paeto? / Ducentiens accepit, et tamen uiuit.

${ }^{43}$ WATSON, P. (1992) 265, usa esse argumento contra BELL, para negar que Marcial fosse pai de Erócion: o poeta não se atreveria a dar um uso espirituoso à morte da filha.

${ }^{44}$ Kenney, E. J. (1964) 80. 
Além disso, alguns anos mais tarde, antes de regressar a Bílbilis, ${ }^{45} \mathrm{O}$ poeta ainda lamenta a morte de Erócion, num belo epitáfio (10.61) em que recomenda ao futuro proprietário do campo, no qual a escrava está sepultada, que preste anualmente homenagem àqueles Manes pequeninos. Em suma, quando as interpretações são complicadas e díspares, a leitura melhor será a mais óbvia.

O lamento da morte dos amigos, das crianças e dos escravos é coerente com o valor que Marcial atribui à vida e o grande pesar motivado pelo corte prematuro do fio. Além de exortar repetidamente a aproveitar cada momento, pois as Parcas não descansam, ${ }^{46}$ distingue coragem de imprudência nas batalhas e condena as guerras, como desejos de insensatos, ${ }^{47}$ e desaprova o suicídio estóico, porque maior mérito reside em enfrentar as dificuldades da existência: «Na adversidade, fácil é menosprezar a vida: / com maior coragem procede quem sabe suportar a infelicidade.».48 Louva o amigo Deciano pelo facto de este, apesar de seguidor dos princípios de Catão e de Trásea, se não lançar de peito aberto sobre as espadas nuas: «Não quero um herói que com sangue fácil compra a fama, / mas aquele que pode ser louvado sem morrer.». ${ }^{49}$

Mas nem sempre a morte é motivo de lamento. Embora contrário ao suicídio estóico, Marcial louva certas mortes corajosas. Perante factos consumados, maior valia haverá em engrandecê-los. Celebra a morte de Festo que, atacado por doença incurável, preferiu ao veneno ou à inanição uma morte à romana, isto é, pela espada (1.78). Mas, neste caso, compreende-se: o resultado seria sempre a morte, e o elogio incide não tanto sobre o suicídio, mas antes sobre a coragem da escolha do instrumento, consonante com os costumes dos antepassados.

$45 \mathrm{O}$ livro $\mathrm{V}$ terá sido publicado entre 89-90; a segunda edição do livro $\mathrm{X}$ em meados de 98 , quando o poeta se preparava para regressar à terra natal. Vide Allen, W. Jr. ET AL., "Martial knight, publisher, and poet": CJ 65 (1970) 351; Sullivan, J. P. (1991) 35 e 44.

${ }^{46}$ Cf. $1.15 .11-12 ; 2.90 .3-4 ; 4.54 ; 5.20 .11-14 ; 5.58 ; 5.64 .5-6 ; 6.27 .10 ; 6.70 ; 7.47 .11-$ $-12 ; 8.44 .1-2$.

47 6.25..7: Bella uelint Martemque ferum rationis egentes.

48 11.56.15-16: Rebus in angustis facile est contemnere uitam: / fortiter ille facit qui miser esse potest.

${ }^{49}$ 1.8.5-6: Nolo uirum facili redemit qui sanguine famam: / hunc uolo, laudari qui sine morte potest. Vide ADAMIK, T., "Martial and the vita beatior ": AUB 3 (1975) 57-60. 
Parecem sobretudo impressionar o poeta certas mortes por amor, seja este por uma pessoa ou por uma causa sublime. No que respeita às mulheres, os tipos descritos nos epigramas são maioritariamente negativos. ${ }^{50} \mathrm{O}$ modelo de amor cantado por Marcial corresponde à mulher de um só marido - uma raridade: ${ }^{51}$ poucas mais se contam, ${ }^{52}$ além de Póla Argentária, viúva de Lucano e exemplo vivo de devoção ao esposo que morreu (7.21-23). É, apesar de tudo, em certas mulheres que o poeta encontra a prova suprema de amor conjugal, ao fazerem seu o destino do esposo, de acordo com os modelos mitológicos de Evadne e Alceste (4.75.5-6). Pórcia (1.42), filha de Catão e esposa de Bruto, que se suicidou depois da batalha de Filipos, consumou os seus intentos, apesar de a tentarem impedir, como já acontecera com o seu pai. Árria, esposa de Cecina Peto, forçado ao suicídio por estar implicado numa conjura contra Cláudio, toma a iniciativa ao mesmo tempo que demonstra o seu amor. A declaração da heroína substitui, no final, o elogio do poeta: «Podes crer: o golpe que abri em mim não me dói, disse ela, / mas o que tu vais abrir em ti, esse sim, Peto, é que me dói!». ${ }^{53}$

A morte voluntária por um bem maior é louvada a Otão. A vida deste breve imperador do ano 69 não se apresentava como modelo de virtude, mas, ao preferir a morte, para evitar o prolongamento da sangrenta guerra civil que se travava entre os seus partidários e os de Vitélio, num momento em que poderia ainda vencer, mostrou um desprendimento que, aos olhos dos contemporâneos, não ficava atrás do de Catão (6.32). ${ }^{54}$

50 Vide MARCHESI, Concetto, "Le donne e gli amori di Marco Valerio Marziale": Rivista d'Italia 13 (1910) 551-598; CHANEY, Virginia M., "Women, according to Martial": CB 48 (1971) 21-25.

51 Tal como descreve a conclusão de um epitáfio de matrona (10.63.7-8): Contigit et thalami mihi gloria rara fuitque / una pudicitiae mentula nota meae.

$52 \mathrm{Um}$ bom exemplo é o caso de Sulpícia, esposa de Caleno: 10.35; 10.38. Nigrina, esposa de Antístio Rústico, dá prova de amor em vida, ao partilhar os seus bens com o marido (4.75), e, depois da morte deste, torna-se modelo de piedade, ao transportar no regaço, desde a Capadócia, onde ele era legado de Domiciano, até Roma, as cinzas do defunto (9.30).

53 1.13: 'Si qua fides, uulnus quod feci non dolet,' inquit, I 'sed tu quod facies, hoc mhi, Paete, dolet.' Cf. Plínio, Ep. 3.16. Vide Sullivan, J. P. (1991) 226-227.

${ }^{54} \mathrm{O}$ seu exemplo é louvado na tradição histórico-biográfica: cf. Plutarco, Oth. 15-18; Tácito, Hist. 2.46-50; Suet. Otho 9-10; Díon Cássio, 64.11-15. 
Para o poeta, a morte é valorizada em correlação com a vida, numa perspectiva epicurista: a uma existência tranquila corresponderá uma morte tranquila. O segredo de não temer nem desejar o último dia reside na forma modelar de viver, como sugere o poeta ao seu amigo Júlio Marcial (10.47). Mas considerará o poeta que viveu como desejava? Bílbilis, a terra da origem e do regresso, parece concretizar, por momentos, o sonho de uma vida simples e calma, ${ }^{55}$ que as cansativas obrigações de cliente the negavam em Roma, e o local ideal para terminar os seus dias: é o que se lê nas palavras que dirige ao amigo Juvenal, que continuava a suportar o "suadoiro da toga" e a azáfama da Urbe (12.18). Mas o sonho em breve se desvanece, como verificamos pela carta desencantada que serve de prefácio ao livro doze dos Epigramas. ${ }^{56} \mathrm{E}$ as palavras com que Marcial encerra o epigrama dirigido a Juvenal, «Assim me apraz viver, assim me apraz morrer!», ${ }^{57}$ tornam-se pressagas, na medida em que, pouco tempo depois, Plínio nos dá notícia da morte do seu amigo.

Somos tentados a pensar que o amor à terra natal lhe terá apressado a morte ao precipitar o regresso. Apesar de encontrar um mecenas em Prisco (12.3; cf. 12. pref.; 12.1; 12.14) e uma benemérita em Marcela (12.31; cf. 12.21), que lhe ofereceu uma pequena quinta, o poeta mostra-se insatisfeito. Se em Roma tinha saudades de Bílbilis, de regresso à Hispânia, confessa a saudade (desiderium) da Urbe (12.21.9-10) que durante trinta e quatro anos o inspirara ${ }^{58}$ e da qual busca agora "os ouvidos". Talvez tenha sucumbido ao desalento ${ }^{59}$ de se sentir um estrangeiro na sua própria terra, amargurado pela má-língua e a inveja de alguns conterrâneos, apartado dos amigos que deixara em Roma. ${ }^{60}$

55 Vide MEdeIros, W. (1988) 3-5; BRANDÃo, J. L. (1998) 25-31 e 52-59.

56 Vide PIMENTEL, Cristina, "Quid petitur? Do sonho e do desencanto em Marcial" : Euphrosyne 21 (1993) 249-261.

57 12.18.26: Sic me uiuere, sic iuuat perire.

58 12. Pref.: (...) illam iudiciorum subtilitatem, illud materiarum ingenium, bibliothecas, theatra, conuictus, in quibus studere se uoluptates non sentiunt, ad summam omnium illa quae delicati reliquimus desideramus, quasi destituti.

59 Sullivan, J. P. (1991) 55, sugere que Marcial se entregou à indolência de uma vida sedentária e ao gosto da comida e do bom vinho, o que lhe terá apressado a morte.

${ }^{60}$ Vide BRANDÃO, J. L., " Marcial e o amor da liberdade", Humanitas (1998) 151-172. 
A tranquilidade que almejava tinha de ser condimentada, como vimos, com a amizade. Escrevera uma vez que desejaria passar o tempo livre, que então não tinha, na companhia de Júlio Marcial. Agora Prisco concedeu-lhe o ócio, tal como outrora Mecenas a Virgílio (12.3), mas o amigo está longe. Nas palavras que lhe dirige, percebe-se uma tristeza tanto maior quanto o fora a intimidade:

«Trinta e quatro colheitas passei eu / contigo, se bem me lembro, Júlio: / uma mistura de prazeres e amargores, / mas as alegrias foram mais sem dúvida; / e se, pedrinha aqui, pedrinha ali, / formassem dois grupos de cores distintas, / a série das brancas venceria a das mais negras. / Se quiseres fugir a certos dissabores / e prevenir as funestas mordeduras da alma, / não te ligues pelo afecto a ninguém em demasia: / terás menos alegrias e menos sofrimentos!». ${ }^{61}$

Parece ser a confissão de quem, apesar de ter obtido as condições materiais que permitiam acesso à ideal uita beatior de cariz epicurista, descrita em 10.47, não conseguira alcançar o recomendado domínio das paixões e consequente ausência de dor, porque o coração humano se não conforma com a fria racionalidade da ataraxia. Ao assumir que descreve o homem, o poeta não pode evitar as contradições inerentes à condição humana. Há em Marcial este dilema entre o valor atribuído aos afectos e as máximas racionais de moderação, que visam evitar o sofrimento. De um lado, o aparente distanciamento emocional, do outro, a profunda empatia para com os simples e desprotegidos. Aconselha a evitar uma afectividade excessiva em relação aos amigos, mas o topos do memento mori é acompanhado da exortação ao cultivo da amizade e o aniversário do amigo é colocado acima do próprio. A morte, ou a consciência da sua proximidade, em especial quando se trata de amigos, de escravos, de crianças quebranta o equilíbrio emocional: faz extravasar os sentimentos e revela a contradição. Se a morte pode apanhar desprevenido o filósofo, ${ }^{62}$ quanto mais o poeta!

61 12.34: Triginta mihi quattuorque messes / tecum, si memini, fuere, Iuli. I Quarum dulcia mixta sunt amaris, / sed iucunda tamen fuere plura; / et si calculus omnis huc et illuc / diuersus bicolorque digeratur, / uincet candida turba nigriorem. / Si uitare uoles acerba quaedam / et tristis animi cauere morsus, / nulli te facias nimis sodalem: / gaudebis minus et minus dolebis.

${ }^{62}$ Cf. Séneca, Ep. 63.14-15. 